\title{
Costs and benefits
}

of government borrowing

in foreign currency: is it

a major source of risk for

EU member states outside

the Euro?

MISLAV BRKIĆ, univ. spec. oec.*

Review article**

JEL: E52, E58, F34, H63

https://doi.org/10.3326/pse.45.1.2

\footnotetext{
* The author would like to thank Igor Ljubaj and two anonymous reviewers for providing useful comments during the preparation of this paper. The views and opinions expressed in this article are those of the author and do not necessarily reflect the official policy or position of the Croatian National Bank.

${ }^{* *}$ Received: June 16, 2020

Accepted: November 10, 2020
}

\section{Mislav BRKIĆ}

Croatian National Bank, Trg hrvatskih velikana 3, 10000 Zagreb, Croatia

e-mail: mislav.brkic@hnb.hr

ORCiD: 0000-0003-3872-4824 


\section{Abstract}

This paper discusses the costs and benefits of government borrowing in foreign currency. While discussing the main costs, such as increased exposure to currency and rollover risks, and limited capacity to respond to financial crises, this paper also identifies two benefits of foreign currency borrowing. The paper also explores to what extent governments of non-euro area EU member states rely on foreign currency borrowing and whether they have sufficient capacity to preserve currency stability in the event of adverse shocks. The analysis suggests that the public finances of these countries are not heavily exposed to currency risk. Exceptions to this are Bulgaria and Croatia, whose government debt is mainly denominated in euros, and who also suffer from high loan and deposit euroization. It is therefore not surprising that they are the first two among the remaining non-euro area $E U$ member states to take steps towards the introduction of the euro.

Keywords: foreign currency, government debt, international reserves, debt crisis, dollarization

\section{INTRODUCTION}

Since the 1970s, it has been illustrated many times that government borrowing in foreign currency can be a major source of risk. Not only does it tend to create currency mismatches and thus expose public finances to exchange rate shocks, but it can also make refinancing of government debt more challenging. In particular, being aware that the government suffers from a currency mismatch, investors can be very sensitive to changes in the country's risk profile. If the risk profile deteriorates, investors may choose to withdraw from its bonds to avoid losses that could occur if the government runs out of foreign currency. In such a context, it can become increasingly difficult for the government to refinance its foreign currency liabilities as they mature. Therefore, if the government is heavily indebted in foreign currency, it becomes vulnerable to self-fulfilling prophecies: investors' worries about a default could easily result in the country actually defaulting on its debt.

Although economic history has clearly taught us that borrowing in foreign currency can be very harmful to macroeconomic stability, even today many countries rely heavily on foreign currency sources of funding. One of the objectives of this paper is to explain why this is so. In addition to discussing the costs and risks, it identifies two main benefits of government borrowing in foreign currency, which are most evident in small, highly dollarized emerging market countries. One of these benefits is that funding sources in major global currencies are typically more abundant and cheaper than local sources of funding in domestic currency. Therefore, in countries where local funding sources are scarce, external borrowing by the government, if allocated to productive projects, can be an important driver of economic growth and development. The second benefit stems from the fact that government borrowing in foreign currency enables the central bank - at least temporarily, as the debt stock is increasing - to accumulate foreign exchange reserves that serve as a backstop for the domestic currency. To illustrate this point, the 
paper shows that government borrowing in foreign currency accounted for almost $40 \%$ of the cumulative increase in Croatia's foreign exchange reserves over the last two decades.

The second objective of this paper is to explore to what extent governments of non-euro area EU member states rely on foreign currency borrowing, and whether they have sufficient capacity to preserve currency stability in the event of a negative shock. The analysis suggests that public finances of these countries are not heavily exposed to currency risk. In most countries, a large majority of outstanding government debt is denominated in domestic currency, leaving public finances largely isolated from exchange rate fluctuations. Exceptions to this are Bulgaria and Croatia, whose government debt consists mainly of euro-denominated liabilities. Given their relatively higher exposure to currency risk, it is not surprising that Bulgaria and Croatia are the first among the remaining non-euro area EU member states to take concrete steps towards the introduction of the euro. However, even these two countries seem to have contained currency risk with their generally strong fiscal and external fundamentals. This was demonstrated in 2020 after the outbreak of the COVID-19 pandemic, when both countries managed to keep their currencies stable despite the adverse economic impact of the necessary disease containment measures.

The main contribution of this paper is that it provides a nuanced overview of the costs and benefits of government borrowing in foreign currency. While borrowing in foreign currency makes a country vulnerable and therefore should be avoided if possible, the paper shows that in some specific cases - such as when the financial system is highly euroized (dollarized) - this can actually be beneficial from the financial stability perspective. In addition, based on an analysis of the currency composition of government debt in EU member states outside the euro area, the paper suggests a potential explanation for why some of these countries are eager to adopt the euro while others are not.

The structure of the paper is as follows. Chapter 2 discusses the main disadvantages and some advantages of government borrowing in foreign currency from the perspective of emerging market countries, taking into account specific features of their economies. Chapter 3 reviews the literature to identify how a country that relies heavily on foreign currency funding can minimize the risk of a currency and debt crisis. Chapter 4 looks into the currency composition of government debt and other macroeconomic fundamentals of non-euro area EU member states to determine whether foreign currency borrowing is a major source of risk for these countries. Chapter 5 concludes the paper. 


\section{COSTS AND BENEFITS OF GOVERNMENT BORROWING IN FOREIGN CURRENCY}

\subsection{COSTS OF FOREIGN CURRENCY BORROWING}

\subsubsection{Exposure to currency risk}

Unhedged foreign currency borrowing is risky because it makes the borrower sensitive to exchange rate fluctuations. If a government borrows in the markets in foreign currency, while generating ( $\operatorname{tax}$ ) revenue exclusively in domestic currency, it will be vulnerable to a potential depreciation of the domestic currency. In the event of a depreciation, the government debt-to-GDP ratio will become larger, while interest expenditures will also increase, negatively affecting the budget balance. If the government, companies and households are indebted in foreign currency at the same time, the entire economy will be heavily exposed to currency risk.

There is a vast literature dealing with the causes and consequences of unhedged foreign currency borrowing. In an influential paper, Eichengreen and Hausmann (1999) note that most developing countries are unable to issue external debt in domestic currency, so they have no other option but to issue debt securities denominated in one of the key global currencies. The inability to borrow abroad in domestic currency is what these authors call "the original sin", because it generates currency mismatch at the aggregate level, which represents a major constraint for policy makers. In particular, in the context of high exposure to currency risk, preserving the stability of the domestic currency usually becomes a top policy priority for the central bank. A strong focus on currency stability, however, narrows the space for flexible use of monetary policy, as remaining policy objectives, such as managing the business cycle, become less important (Eichengreen, Hausmann and Panizza, 2003). As a result, countries that borrow in foreign currency tend to have a higher degree of macroeconomic volatility than those that borrow mainly in their own currency.

The impact of currency depreciation on public finances is very straightforward. If part of the government debt is denominated in or indexed to foreign currency, that part will mechanically increase (expressed in domestic currency) in line with the strengthening of the foreign currency, generating a step increase in the debt-toGDP ratio (figure 1). In addition, annual interest expenses will increase due to the now higher debt stock, even if the average interest rate is unaffected. However, it is very likely that, following a large depreciation of the currency, the country's risk premium would rise, making new government borrowing costlier. This would produce second-round effects because a higher average interest rate would entail even higher interest expenses, with an adverse impact on the government budget balance and the debt trajectory. 
Impact of a currency depreciation on the public finances

a) Government gross debt, in \% of GDP

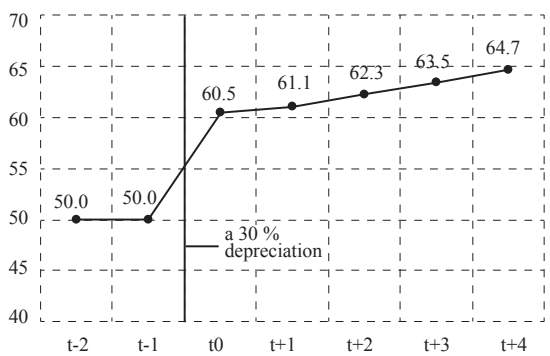

b) Government balance, in \% of GDP

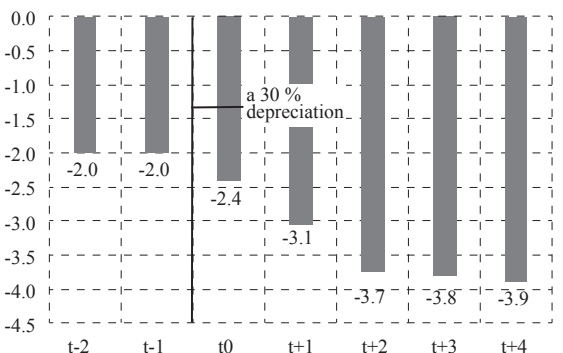

Note: The simulation is performed assuming that the initial debt-to-GDP ratio is $50 \%$, the primary deficit is zero, the share of foreign currency debt in total government debt equals $70 \%$, the nominal GDP growth rate is $4 \%$, while the weighted nominal interest rate on debt, initially set at $4 \%$, increases following the depreciation of the currency to $5 \%$ in $t+1$, and further to $6 \%$ in $t+2$, remaining stable thereafter.

Source: Author.

What could cause currency depreciation in a country that is heavily borrowing in foreign currency? Several factors can lead to such an outcome, with banking system fragility being one of the most common triggers. ${ }^{1}$ Specifically, if banks have large, uncovered short-term foreign currency liabilities, the decision of creditors and depositors to call on their loans and withdraw their deposits will put a strain on the banks' limited stocks of liquid foreign currency assets (Chang and Velasco, 1999). Due to the shortage of foreign currency relative to domestic currency, the domestic currency would depreciate, forcing the central bank to deploy international reserves in an attempt to stabilize the currency. An extreme example of such a scenario was the financial crisis in Iceland in 2008. This event clearly demonstrated how an oversized and poorly regulated banking system could bring down the currency and the economy as a whole (Claessens, Herring and Schoenmaker, 2010). Furthermore, currency depreciation may occur if investors, concerned about the country's deteriorating macroeconomic fundamentals ${ }^{2}$ or inflated asset prices, begin to liquidate their positions in government bonds and other domestic currency-denominated securities. The risk of a destabilizing sell-off of domestic currency assets is less pronounced in countries with shallow capital markets. In these countries, the supply of securities denominated in domestic currency is

\footnotetext{
${ }^{1}$ Kaminsky and Reinhart (1999) empirically investigated the link between banking and currency crises. They found that banking and currency crises often coincide, with the banking typically preceding the currency crisis. The currency crisis in turn aggravates the banking crisis, creating a vicious circle with an adverse impact on the real economy. However, although banking crises usually start before currency crises, they are not necessarily the immediate cause of currency crises. In fact, two crises are sometimes manifestations of the same root cause - excessive credit growth backed by favourable access to international financial markets.

${ }^{2}$ Frankel and Rose (1996) found that the likelihood of a currency crisis is high when international reserves are modest, the share of FDIs in total external debt is low, the real exchange rate is overvalued, credit growth is strong and interest rates in the advanced economies are rising. Most of these variables are identified as critical also by Sachs, Tornell and Velasco (1996).
} 
limited, so there is little risk that transactions in the securities market will exert strong downward pressure on the currency.

\subsubsection{Increase in refinancing risk}

Apart from giving rise to currency risk, foreign currency borrowing is associated also with greater refinancing (rollover) risk. In fact, these two risks are mutually reinforcing. The former risk tends to exacerbate the latter, in the sense that a large presence of currency risk may trigger the materialization of refinancing risk. The link is quite intuitive: if a government borrows in foreign currency, its creditors will be indirectly exposed to currency risk, because a sharp depreciation of the domestic currency may reduce the government's ability to meet its foreign currency obligations. ${ }^{3}$ Therefore, in the event that creditors suspect that the borrower's currency might lose ground, they would no longer be interested in financing the borrower. As a result, the government would be forced to repay its foreign currency liabilities as they fall due, which, if large sums have to be repaid within a short time period, could lead to a debt and currency crisis. In such a case, the only remaining option for the government - if it wants to avoid defaulting on its foreign currency debt - would be to seek international financial assistance.

There are numerous historical examples of debt crises caused by excessive foreign currency borrowing. Indeed, financial crises in emerging market countries are usually preceded by periods of abundant inflow of foreign currency funding. Namely, if global financial conditions are favourable, emerging market countries will have an incentive to import capital from abroad to finance domestic consumption and investment at low cost. The favourable impact of externally funded spending on output and employment will reflect positively on consumer and business confidence and thus lead to an even higher propensity to borrow and spend. If left unaddressed, excessive external borrowing might lead to an unsustainable expansion of domestic demand and leave the economy vulnerable to external shocks. As these shocks tend to emerge abruptly, emerging market countries are often caught by surprise. External shocks can take various forms, ranging from sudden changes in global monetary conditions, deteriorating investor confidence ${ }^{4}$, falling prices of the main export commodities, to main trading partners announcing protectionist measures ${ }^{5}$. Irrespective of the type of the external shock, the shock usually leads to a deterioration in the borrowing country's access to external financing. The most widely known examples of such events are the crises in Latin America in the 1980s and 1990s.

\footnotetext{
${ }^{3}$ This risk is often referred to as foreign currency-induced credit risk because the materialization of currency risk on the side of the borrower leads to the materialization of credit risk for the creditor.

${ }^{4}$ A deterioration in investor confidence may concern a single country or a group of countries sharing similar characteristics. A notable example of a broad-based confidence shock was the so-called "taper tantrum" of May 2013. As the Federal Reserve announced that it was considering winding down its program of unconventional monetary policy measures, a sudden reassessment of global risk premiums took place, which had a negative effect on several emerging market economies that were vulnerable at the time due to elevated macroeconomic imbalances (Sahay et al., 2014).

${ }^{5}$ For instance, in November 2016 the Mexican peso depreciated sharply against the dollar following Donald Trump's victory in US presidential elections, as investors feared that the new President would keep his campaign promise to revise the North American Free Trade Agreement (NAFTA) (Banco de Mexico, 2017).
} 
The debt crisis in Latin America in the early 1980s was a consequence of the borrowing spree that took place during the previous decade. In the 1970s, countries such as Argentina, Brazil and Mexico borrowed heavily abroad in US dollars to cover their large balance of payments needs. By the late 1970s, it had become clear that the rapid accumulation of debt was not sustainable and that external adjustment was needed (Federal Deposit Insurance Corporation, 1997). Despite that, foreign banks, especially those from the US, continued to increase their lending to the region. The situation, however, changed dramatically at the beginning of 1980s, when the Federal Reserve (Fed) tightened monetary policy to combat high inflation in the US. This had a devastating impact on the heavily indebted Latin American countries. Not only did interest rates on their foreign liabilities increase, but also their national currencies depreciated considerably against the US dollar, increasing the repayment burden of large stocks of US dollar liabilities. While most Latin American countries continued to service their liabilities without defaulting, the heavy repayment burden contributed to a deep and prolonged recession, which lasted for most of the decade.

Heavy government borrowing in foreign currency was also a major factor behind the 1994 Mexican crisis. In light of Mexico's pronounced macroeconomic imbalances and large refinancing needs on the domestic front, and deteriorating global monetary conditions on the external front, investors were worried that the Mexican authorities would be unable to defend the peso from depreciating. These fears were further exacerbated by domestic political instability, which culminated in late 1994, triggering significant capital outflows (IMF, 2012). The liquidity crisis soon transformed into a currency and debt crisis, prompting Mexican authorities to seek financial assistance from the US and IMF.

Vulnerability to recurrent debt and currency crises are not an exclusive feature of the modern globalized economy characterized by flexible exchange rates and extensive cross-border financial flows. These disruptive events have occurred from time to time throughout history, even when the entire world relied on fixed exchange rates and when gross capital flows were subdued by modern standards. A notable case is the default of Germany from the early 1930s. Germany had returned to the gold standard by the mid-1920s, after which it borrowed heavily in foreign currency, mainly to obtain the gold and convertible currencies needed to settle large reparations following its World War I defeat (Ritschl, 2013). In 1929, a revised, much more demanding reparations agreement was announced, which raised concerns among creditors and resulted in Germany losing access to external financing. The outbreak of the Great Depression further exacerbated the already dire situation. Confronted with large refinancing needs and a rapid loss of international reserves, in 1931 the German central bank imposed capital controls. Finally, in 1933, Germany declared a default on most of its foreign liabilities. 


\subsubsection{Reduced ability to tackle financial crises}

The episodes of debt crisis documented above illustrate how excessive foreign currency borrowing can make countries vulnerable to self-fulfilling prophecies. ${ }^{6}$ The vulnerability to sudden shifts in investor confidence stem from the borrowing country's inability to create the foreign currency needed to repay the creditors if many of them decide to withdraw funding at the same time. In contrast, countries with the privilege of borrowing exclusively in domestic currency do not suffer from the same weakness.

While borrowing in domestic currency does not eradicate the risk of a debt crisis altogether, it indirectly enables the country to cope better with the crisis should it occur. In particular, if both the government and the private sector borrow mainly in domestic currency, the central bank will be less concerned about exchange rate fluctuations. Owing to this, the central bank will be able to lend freely to commercial banks in times of crisis to contain liquidity disruptions. Liquidity disruptions are very common during sovereign debt crises, as depositors may become concerned about the possible adverse impact of the crisis on bank solvency. By acting as lender of last resort, the central bank provides fundamentally healthy banks with additional cash needed to meet the increased withdrawal requests. This not only helps cure liquidity problems in the banking system, but it also enables the government to refinance its debts with commercial banks at favourable terms.

The European sovereign debt crisis of 2010-2012 has shown very clearly that central bank emergency lending can have an instrumental role in containing the fallout from the crisis. At the height of the sovereign debt crisis, the Eurosystem - consisting of the ECB and the euro area national central banks - provided massive amounts of liquidity to Greek, Irish, Portuguese and Spanish banks, which had almost completely lost access to market funding (figure 2). There is no doubt that the debt crisis in Europe would have been much worse had the Eurosystem not intervened to prevent the collapse of peripheral countries' banking systems. In addition to enhanced liquidity provision to banks, which indirectly assisted the vulnerable governments to obtain the much needed funding, the Eurosystem implemented several measures aimed directly at tackling the turmoil in the sovereign debt market.?

The ECB's virtually unlimited capacity to act as crisis manager came into focus again in 2020 after the outbreak of the COVID-19 pandemic. While member states initially failed to reach an agreement on a common fiscal response to the crisis, by mid-March 2020, the ECB had already stepped in by announcing the Pandemic Emergency Purchase Programme (PEPP) worth EUR 750 billion. ${ }^{8}$

\footnotetext{
${ }^{6}$ There is a large body of literature dealing with the vulnerability of emerging market countries to self-fulfilling panics (Obstfeld, 1986; 1994; Eichengreen, Rose and Wyplosz, 1995; Flood and Marion, 1996; Cole and Kehoe, 2000).

${ }^{7}$ For a review of unconventional policy measures of the ECB, see Constancio (2012), Gros, Alcidi and Giovanni (2012) and Micossi (2015).

${ }^{8}$ In June 2020, the ECB decided to scale up the total size of the program from EUR 750 billion to EUR 1,350 billion.
} 
Under this program, the ECB has been purchasing large amounts of euro area public and private sector securities each month in order to prevent borrowing costs from increasing significantly. Such an intervention by the ECB was critical in the acute phase of the crisis as it eased pressures on the countries particularly affected by the pandemic and enabled their governments to finance healthcare spending and economic relief programs at low cost. Central banks of other advanced countries took similar actions in response to the crisis.

\section{Figure 2}

\section{Borrowing from the Eurosystem as percent of banks' total liabilities}

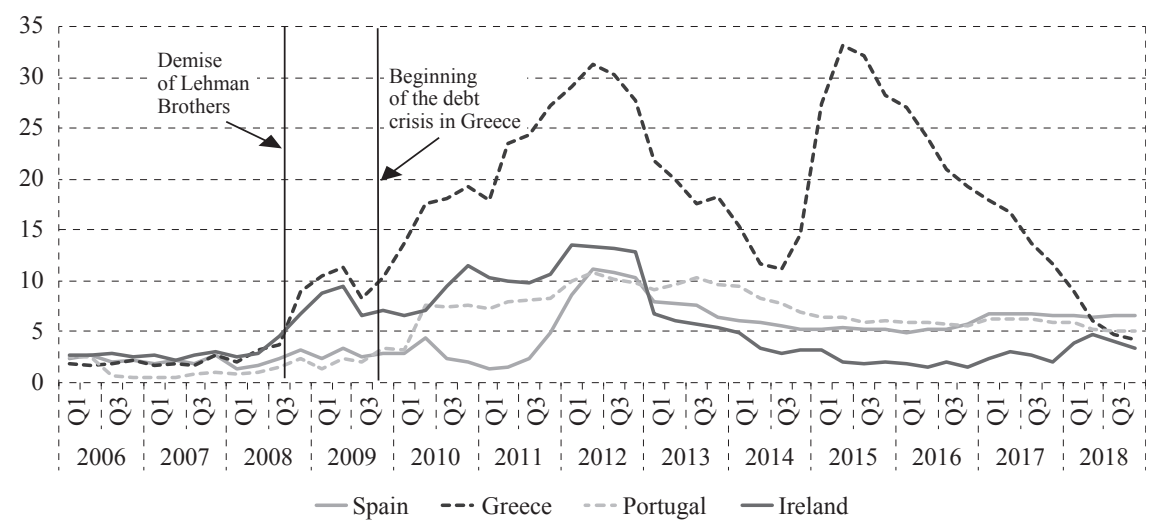

Sources: ECB SDW; author's calculation.

The capacity of the central bank to tackle financial crises is much lower in countries where liabilities of the government and other sectors are mainly denominated in foreign currency. There are at least three reasons for this. First, if government debt is denominated mainly in foreign currency and the government experiences refinancing difficulties, the central bank can provide support only to a limited degree, as it can only create domestic currency. ${ }^{9}$ Second, if liabilities of commercial banks, such as deposits and received loans, are largely denominated in foreign currency, the provision of domestic currency liquidity by the central bank will fall short of mitigating liquidity disturbances in the banking system. What banks need in case of liquidity disturbances is foreign currency. ${ }^{10}$ Third, in dollarized countries, massive purchases by the central bank of government bonds or heavy lending to commercial banks in local currency would be imprudent as it could fuel

\footnotetext{
${ }^{9}$ The capacity of the central bank to support government debt in foreign currency is limited by the size of its foreign exchange reserves. On the other hand, the capacity to intervene in domestic currency funding markets is not directly determined by the level of foreign exchange reserves. At the peak of the COVID-19 crisis, several emerging market central banks pursued unconventional monetary policies to support their economies, including the purchase of government debt securities denominated in domestic currency (IMF, 2020a). However, for such programs to be credible, the central bank should have comfortable foreign exchange reserves to assure financial markets that the newly created money will not lead to a currency devaluation.

${ }^{10}$ The first thing the central bank will do in such a context is reduce the reserve requirement to release banks' own foreign currency liquidity buffers. If these buffers prove insufficient, the central bank may decide to sell a portion of its foreign exchange reserves to banks through foreign exchange interventions or swap transaction. Obviously, the ability of the central bank to supply foreign currency to banks in this way is constrained again by the available stock of foreign exchange reserves (Chang and Velasco, 1998).
} 
speculation against the currency and lead to a harmful depreciation of the exchange rate. Hence, in heavily dollarized countries, the ability of the central bank to act as lender of last resort is significantly weakened, and so is the ability of these countries to tackle banking and sovereign debt crisis on their own. In this respect, dependence on foreign currency borrowing could definitely be considered a "curse" because it makes the country both more likely to experience a financial crisis and less capable of managing the crisis if one occurs.

\subsection{BENEFITS OF FOREIGN CURRENCY BORROWING}

\subsubsection{Lower cost of financing}

Currency risk is non-existent and refinancing risk is typically lower when debts are denominated in domestic currency. The question arises then why some borrowers decide to take on debts in foreign currency when it is far more risky than borrowing in domestic currency. The main reason is that funding in major global currencies, such as the US dollar and the euro, tends to be cheaper and more abundant, especially for small open economies. Specifically, if the domestic financial sector is relatively small, the local supply of financing may not be sufficient to satisfy the overall demand for credit at a favourable cost. This may encourage the government and other borrowers to seek cheaper financing abroad, either directly - by obtaining loans from foreign banks or issuing bonds in international markets, or indirectly - by borrowing from local banks that import capital to finance domestic lending. Since only a handful of countries are able to borrow abroad in their own currencies, external borrowing in most cases results in increased exposure to currency risk.

Moreover, even when borrowing takes place in the domestic market, debts are often indexed to foreign currency. As Claessens, Schmukler and Klingebiel (2007) explain, small countries typically have limited local investor bases, and thus may prefer issuing government securities linked to a major currency in order to attract foreign investors. The additional demand coming from foreign investors will likely ensure both greater availability and lower cost of funding for the government.

Borrowing in foreign currency may facilitate investment and economic development to the extent that it provides the country with more affordable financing and that the borrowed funds are channelled to productive sectors. In particular, if the country is underdeveloped, the government can borrow abroad to carry out productive investment, such as large infrastructure projects, which set the stage for higher growth in the future. In this way, by importing additional capital from abroad, the government eases the pressure on scarce local sources of funding, so that crowding-out of private investment does not occur. Policy makers need to ensure that funds borrowed from abroad are not channelled to excessive domestic consumption, which could lead to economic overheating. Having in mind the large number of financial crises which were caused by excessive external borrowing and spending, it is safe to say that emerging market countries have not been very successful in managing capital inflows. For example, Kaminsky, Reinhart 
and Végh (2005) found that in emerging market countries the size of net capital inflows is positively correlated with the level of government consumption, suggesting that fiscal policy tends to be procyclical.

\subsubsection{Contribution to financial stability in highly euroized (dollarized) countries}

In some circumstances, foreign currency borrowing can also be vital to maintaining financial stability. In particular, if the government is already heavily indebted in foreign currency, its sustained ability to borrow in foreign currency is important so that it can refinance the maturing debt without depleting international reserves. In the event that the government is cut off from international financial markets, it will have to purchase foreign currency in the domestic market to repay its debts, which may destabilize the domestic currency and ultimately lead to its collapse. The crisis events mentioned earlier clearly support this claim.

Moreover, government borrowing in foreign currency can be beneficial for financial stability if the banking system is highly dollarized. One of the main problems associated with dollarization is that central banks in such countries cannot perform the role of lender of last resort at full capacity (Chang and Velasco, 2002). The reason is that if liabilities of commercial banks are denominated in foreign currency, in the event that they face a liquidity crisis, the central bank cannot help them by printing domestic currency. Under these conditions, the capacity of the central bank to act as lender of last resort will depend entirely on the size of its foreign exchange reserves: the large the reserves, the higher the capacity of the central bank to intervene. ${ }^{11}$ In this respect, the inflow of foreign currency liquidity through government borrowing may be helpful as it enables the central bank to set up foreign currency reserves that can later be used to contain liquidity disturbances in the banking system.

Government borrowing as a channel of reserve accumulation is particularly important in countries such as Croatia, where the problem of dollarization is mostly internally created, rather than being a reflection of banks' external borrowing. Specifically, in some countries citizens have a strong preference for saving in major foreign currencies, such as the euro or the US dollar, although most of them do not have any earnings in foreign currency. Therefore, depositors technically bring the domestic currency into a bank, and leave the bank with a foreign currency claim on the bank. Although no hard currency was brought to the bank, the bank ended up with a foreign currency deposit as a liability on its balance sheet. To protect itself from exchange rate fluctuations, the bank will probably grant loans denominated in or indexed to foreign currency, effectively passing the currency risk on to its clients. Under these conditions, the central bank will seek to

\footnotetext{
${ }^{11}$ However, in the case of a severe banking crisis, even large foreign exchange reserves may prove insufficient to contain the turmoil in the banking system and support the currency at the same time. An example of this is the Latvian crisis from 2008, when a dramatic outflow of foreign currency deposits from a major bank led to a rapid depletion of central bank reserves, which undermined the credibility of the currency peg. This in turn prompted the Latvian authorities to request international financial assistance (Purfield and Rosenberg, 2010; IMF, 2009).
} 
build up sufficient foreign exchange reserves so that it is able to defend the domestic currency and the easiest way to accumulate reserves is to acquire foreign currency that the government has imported from abroad.

\section{Figure 3}

\section{Government foreign currency borrowing and reserve accumulation in Croatia}

a) International reserves and net purchases of foreign currency from banks and the Ministry of Finance, in EUR billion

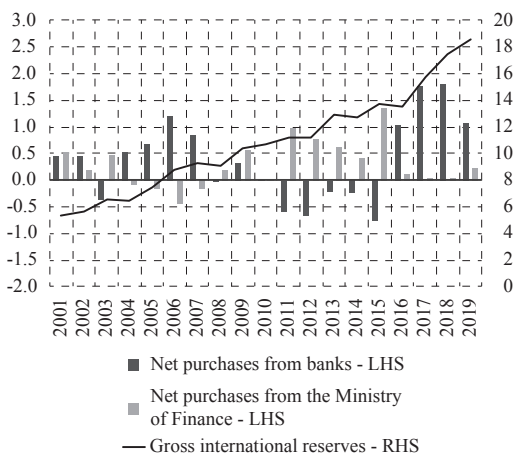

b) Contributions to the cumulative increase in international reserves in the period 2001-2019

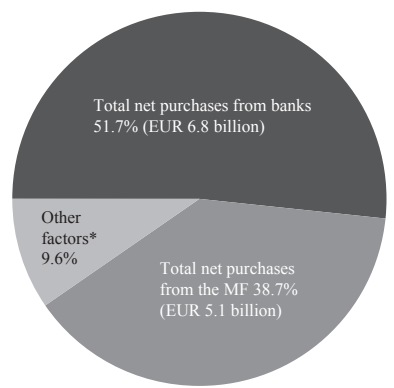

* Other factors relate to exchange rate changes and transactions with the EU budget.

Source: CNB; author's calculation.

Figure 3 shows that government borrowing has been a major factor behind the accumulation of reserves in Croatia over the last two decades. From 2001 to 2019, the reserve assets of the Croatian National Bank increased cumulatively by EUR 13.2 billion (from 5.3 to 18.6 billion), with outright purchases of foreign currency from the Ministry of Finance accounting for EUR 5.1 billion (38.7\%) of the total increase. Clearly, government borrowing boosted the reserves particularly in the aftermath of the global financial crisis when Croatia issued large amounts of foreign currency debt to finance persistent fiscal deficits (CNB, 2012). From 2016 to 2019 , with the fiscal deficit turning into a surplus, the Croatian government merely refinanced the maturing foreign currency debt without incurring additional debt. As a result, the net purchases of foreign currency from the Ministry of Finance decreased significantly. This, however, changed in 2020, as high fiscal spending to contain the economic fallout of the COVID-19 pandemic required additional financing from abroad (CNB, 2020).

Finally, a minor benefit of government borrowing in foreign currency is that it enables the central bank to acquire foreign assets that indirectly generate revenue for the state budget. To be specific, if the government borrows in foreign currency to finance fiscal expenditures in the local economy, the foreign currency liquidity collected by government borrowing will be exchanged at the central bank for domestic currency. The central bank in turn invests this foreign currency liquidity, as part of its foreign exchange reserves, in some high quality assets abroad, such as low-risk government bonds and bank deposits. Given that in normal times these 
assets carry a positive interest rate, the central bank makes a profit from managing them. ${ }^{12}$ As most central banks - after covering their operational expenses - allocate a large part of their profits to the state budget, the government indirectly makes some revenue from the assets purchased with the proceeds of external borrowing. These revenues make the ultimate cost of the government's external borrowing effectively lower. ${ }^{13}$

Admittedly, government borrowing in foreign currency cannot be a source of reserve accumulation indefinitely. At some point, the government debt-to-GDP ratio must stabilize, or otherwise debt sustainability will be jeopardized. In such conditions, the government will merely refinance the existing foreign currency liabilities or even partly repay them in order to reduce the exposure to currency risk. Reducing foreign currency debt is prudent and beneficial if carried out in a favourable macroeconomic environment when the country's balance-of-payments position is strong, as has been the case in Croatia in recent years. As it is shown later in this paper, persistent current account surpluses and abundant domestic currency liquidity have enabled the Croatian government to improve somewhat the currency composition of debt without depleting foreign exchange reserves.

\section{HOW CAN A COUNTRY THAT BORROWS IN FOREIGN CURRENCY REDUCE THE RISK OF A DEBT CRISIS?}

As discussed in the previous chapter, government borrowing in foreign currency can make a country more exposed to debt and currency crises. The mechanism that is activated during sovereign debt crises resembles the one that is at work during bank runs. Diamond and Dybvig (1983) defined the bank run as an undesirable equilibrium in a setup where banks are mainly financed by demand deposits. If depositors lose confidence in a bank and begin withdrawing deposits on a large scale, the bank will have trouble meeting their requests because only a fraction of its assets is held in the form of cash. Eventually, the bank will be forced to liquidate part of its assets at a loss, which can lead to its insolvency. A similar chain of events leads to a sovereign debt crisis: when bondholders become unsure whether a country can continue servicing its debt, the country is forced to repay its liabilities at maturity, which is difficult to achieve if access to funding is impaired.

There are certain mechanisms that have proven effective in preventing bank runs, such as well-enforced prudential regulation and supervision, deposit insurance schemes and central bank lender-of-last-resort lending. Minimizing the risk of a

\footnotetext{
${ }^{12}$ There are, indeed, some alternative sources of revenue for the central bank other than foreign exchange reserves. In particular, central banks typically charge commercial banks a positive interest rate on repo loans granted through regular monetary operations. In addition, if the central bank implemented a government bond purchase program, it could earn interest on bonds accumulated during the implementation of the program. This interest revenue, however, would at some stage be paid back to the state budget as part of the distribution of central bank profits.

${ }^{13}$ As an example, if the government issues a bond internationally with a coupon rate of $4 \%$, and the central bank makes $1.5 \%$ on the reserve assets it acquired after converting the bond placement proceeds into domestic currency, the effective nominal interest rate on the bond will be roughly $2.5 \%$ (assuming that all central bank profits are allocated to the state budget).
} 
sovereign debt crisis when the government is indebted in foreign currency is even more challenging than setting up safeguards for the banking system. The main approach is, however, similar: it is crucial to ensure that liquidity buffers - in the form of foreign exchange reserves - are abundant and that the country's macrofinancial fundamentals are sound.

\subsection{THE ROLE OF FOREIGN EXCHANGE RESERVES}

The benefits of having ample foreign exchange reserves are manifold (Ljubaj, 2019). If reserves are large enough, they shield the currency from excessive fluctuations and speculative attacks, guarantee that the country is capable of conducting international transactions in convertible currencies, and boost the country's credibility in the financial markets. As a result, the likelihood of a currency crisis tends to be low when reserves are abundant. ${ }^{14}$

Maintaining ample foreign exchange reserves is particularly important in countries where the government is heavily indebted in foreign currency. A large stock of reserves provides assurance to investors that the government will be able to continue servicing its foreign currency liabilities even if it temporary loses access to financial markets. As mentioned earlier, if the financial system is dollarized, foreign exchange reserves play an additional important role, as they enable the central bank to assist banks in the event of a liquidity crisis.

\section{Figure 4}

Composition of central bank assets, end-2018 (in \%)

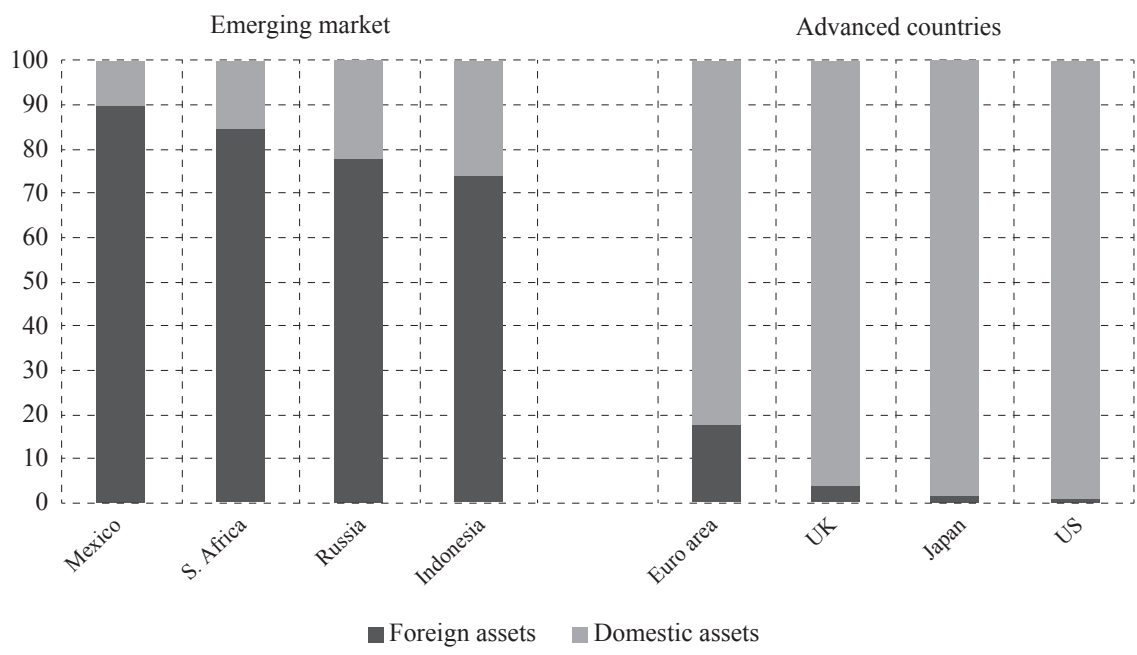

Source: IMF (2020b).

\footnotetext{
${ }^{14}$ Most studies that deal with currency crises identify inadequate reserves as one of the best early warning indicators of currency crises (Kaminsky, Lizondo and Reinhart, 1998; Kruger, Osakwe and Page, 1998; Vlaar, 2000; Abiad, 2003; Babecky et al., 2012).
} 
Hausmann, Panizza and Stein (2001) found that emerging market countries, which borrow abroad mainly in foreign currency, are more concerned about exchange rate volatility than advanced countries. For that reason, emerging market countries tend to maintain much larger stocks of foreign exchange reserves that allow them to intervene in the foreign exchange market if pressures on the currency emerge. The data strongly support this view. Figure 4 depicts the composition of central bank assets for a sample of four large advanced and four large emerging market countries. Clearly, there is a large difference between advanced and emerging market countries in the relative shares of foreign assets in central banks' balance sheets. While in the selected emerging market countries foreign assets account for more than three quarters of total central bank assets, in large advanced countries the share of foreign assets is typically very low.

\subsection{THE ROLE OF OTHER MACRO-FINANCIAL FUNDAMENTALS}

The most effective instrument in preventing a sovereign debt crisis is obviously prudent fiscal policy. By maintaining a balanced budget and keeping the debt-toGDP ratio low enough, the government will minimize the risk of a sudden loss of access to financing. Conversely, if the fiscal deficit is excessive and government debt is large and rapidly increasing, investors will have every reason to worry about debt sustainability. It should be noted, however, that weak fiscal indicators do not necessarily lead to a debt crisis immediately. If global monetary conditions are loose and investors' risk appetite is high, the country may enjoy favourable financing conditions for some time despite its poor fiscal performance. However, due to weak fundamentals, the country will be increasingly sensitive to self-fulfilling prophecies, as illustrated by the Greek sovereign debt crisis (Higgins and Klitgaard, 2014).

The maturity of debt also matters. ${ }^{15}$ The longer the average maturity of government debt, the less vulnerable the country is to sudden changes in market sentiment. In particular, when debt repayment dates are spread over a long period, a transitory shock that raises government bond yields will only affect the portion of the debt that matures during a period when the impact of the shock is noticeable, while the rest will not be affected. In contrast, if the average maturity of government debt is short, many liabilities will have to be refinanced in an unfavourable market environment, which can be very expensive and in some cases even impossible. In most of the crisis episodes documented in the previous chapter, the main problem was that countries relied too heavily on short-term external financing.

Not only should a responsible fiscal policy be conducted but due attention should be devoted to monetary and financial sector policies. As is generally accepted today, monetary policy should focus on keeping inflation in check. By keeping the inflation rate close to the inflation rates of the main trading partners, the central bank can prevent the harmful overvaluation of the currency. With regard to

\footnotetext{
${ }^{15}$ An event that clearly confirms the importance of the maturity composition of government debt is the 1994 Mexican crisis, which was triggered by a run on short-term US dollar-denominated government liabilities called Tesobonos (Sachs, Tornell and Velasco, 1996).
} 
financial sector policies, authorities should exercise vigilant supervision and proactively use micro and macro-prudential regulation, because errors in this area may have negative consequences for the public finances. ${ }^{16}$ Macro-prudential regulation has become increasingly popular in the aftermath of the global financial crisis (Dumičić, 2015). Not only does it help increase the resilience of banks through the introduction of various capital buffers, but it also enables authorities to tackle broader macroeconomic risks by slowing down rapid credit growth and preventing banks from relying on unstable external funding sources.

Weak fundamentals can lead to a debt crisis even if the government debt is denominated entirely in domestic currency. The European sovereign debt crisis of 20102012 is very illustrative in this respect. Each of the countries affected by the debt crisis had borrowed almost exclusively in euros, their domestic currency, but this did not protect them from losing access to market funding when the crisis escalated. Investors were no longer willing to lend to peripheral euro area countries because of the serious weaknesses in their public finances and banking systems. In Greece and Portugal, the main source of vulnerability was the rapidly growing government debt created by persistently high budget deficits. Ireland and Spain, on the other hand, experienced a rapid rise in debt not due to irresponsible fiscal policy but because of costly government intervention to recapitalize failing banks (Brkić, 2019).

\section{ARE PUBLIC FINANCES IN THE EU EXPOSED TO CURRENCY RISK? 4.1 FOREIGN CURRENCY BORROWING IN NON-EURO AREA EU MEMBER STATES}

Some non-euro area EU member states borrow heavily in foreign currency, predominantly in euros. This applies above all to countries from Central and Eastern Europe (CEE), which have shallow local financial markets and therefore often rely on external sources of funding. By contrast, in the northern non-euro area member states - Denmark and Sweden - foreign currency borrowing is not a systemic problem. In these advanced countries, foreign currency borrowing is mainly used by export-oriented firms to protect against foreign exchange risk, while households and the government sector typically do not have large unhedged foreign currency exposures. ${ }^{17}$

\footnotetext{
${ }^{16}$ As the recent crises in Iceland, Spain and Ireland have shown, even if fiscal indicators are generally sound, debt sustainability may soon come into question if severe losses in systemically important banks force the government to implement costly recapitalization programs in order to avoid the collapse of the banking system. ${ }^{17}$ At the end of 2018, the Danish government had virtually no foreign currency liabilities (Danmarks Nationalbank, 2019). Although about a quarter of Sweden's government debt is denominated in foreign currency, the level of foreign currency exposure is much lower as the national debt office has purchased large amounts of foreign currency in recent years to reduce the exposure to currency risk (Swedish National Debt Office, 2019).
} 


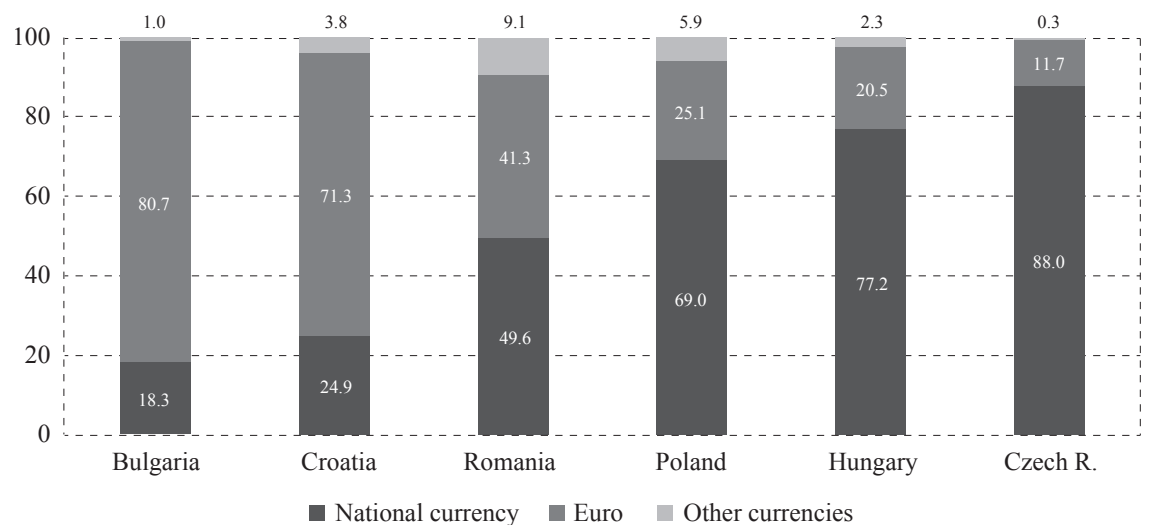

Source: Eurostat (2020a).

Figure 5 depicts the currency composition of government debt for six EU member states from CEE. While the share of foreign currency debt is on average notably higher than in the northern member states, there is a substantial difference between individual CEE countries in the reliance on foreign currency funding. Two countries, Bulgaria and Croatia, stand out, with more than three quarters of total government debt denominated in or indexed to foreign currency. ${ }^{18}$ Vulnerability of public finances to exchange rate fluctuations is also high in Romania, where government debt is split equally between the national currency and foreign currency components. Conversely, as figure 5 clearly indicates, currency risk is much less of a concern in Poland, Hungary and, in particular, the Czech Republic.

Being indebted in foreign currency is not problematic for a country if its access to external markets is maintained and the exchange rate is stable. However, if for some reason the local currency begins to lose ground against the foreign currency in which debt is denominated, the government will see its debt ratio increase. Figure 6 illustrates a simple, back-of-the-envelope simulation of the impact of a currency depreciation on the debt-to-GDP ratios. Obviously, in case of a depreciation, countries that have large portions of debt linked to foreign currency, such as Bulgaria and Croatia, will experience a much stronger relative deterioration of the debt-to-GDP ratio than countries that rely less on foreign currency funding. When interpreting these results it should be borne in mind that initial debt levels differ across countries, because this affects the absolute change in the debt-to-GDP ratio following the currency depreciation. Specifically, although Bulgaria has the highest share of foreign currency debt in this group of countries, due to its low initial debt ratio the absolute increase in the debt ratio is not very large. In the event of a $20 \%$ depreciation,

\footnotetext{
${ }^{18}$ While Bulgaria borrows almost exclusively in euros, a small part (less than 5\%) of Croatia's government debt is denominated in US dollars. However, given that the Croatian government uses EUR/USD currency swaps to hedge the exposure to the US dollar, its public finances are sensitive only to fluctuations in the EUR/ HRK exchange rate (MoF, 2017).
} 
Bulgaria's debt ratio would increase by 3.6 percentage points of GDP, which is only slightly higher than the values for Romania and Hungary ( 3.5 and $3.2 \mathrm{pp}$, respectively), and much lower than the absolute increase for Croatia (11.2 pp).

\section{Figure 6}

\section{Exposure of public finances to currency risk, 2018, in \% of GDP}

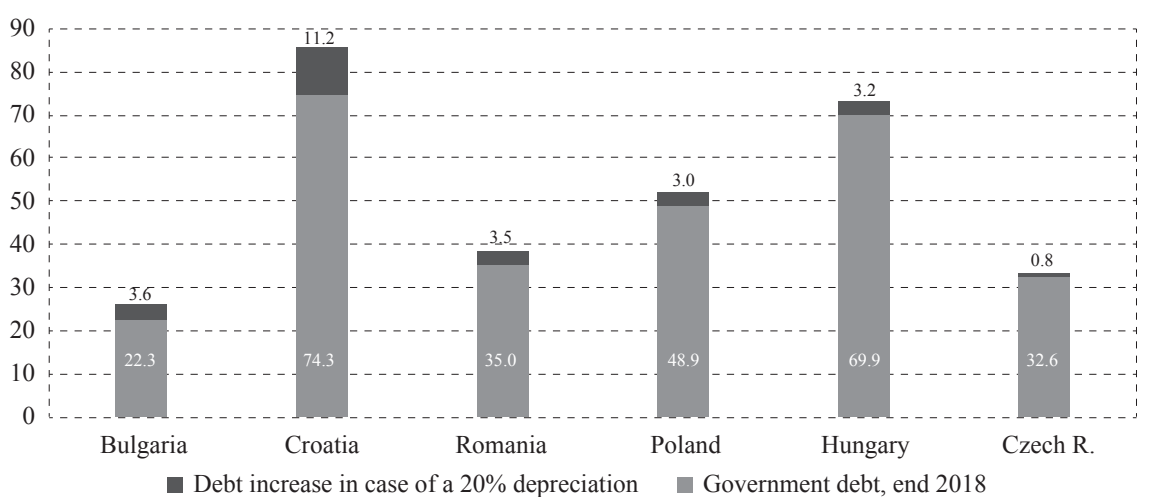

Source: Eurostat (2020a); author's calculations.

As figure 7 shows, the same countries that stand out with a particularly high share of foreign currency debt in total government debt are the countries that have the most heavily euroized banking systems. Specifically, in Bulgaria and Croatia, foreign currency deposits account for a large share of total banking system liabilities, while this is not the case in countries such as Poland or the Czech Republic. The link between the currency composition of government debt and the degree of euroization is not surprising given that local banks are typically among the main holders of government debt instruments issued in the domestic market. If a large part of their liabilities is denominated in foreign currency, banks will prefer to invest in foreign currency assets to hedge against currency risk. Since local banks are key investors in government debt securities, the government will naturally consider their preferences when deciding in which currency treasury bills or bonds will be issued. ${ }^{19}$ Due to this, in highly euroized countries the share of foreign currency debt in the currency composition of government debt is typically higher than the share of debt held by non-residents in the ownership composition of government debt. ${ }^{20} \mathrm{In}$ other words, it is not only the external part of government debt that is denominated in foreign currency, but also a major share of the domestic debt.

\footnotetext{
${ }^{19}$ In addition to investing in foreign currency-denominated debt securities issued domestically, local banks with a preference for foreign currency assets may also purchase Eurobonds issued by the government in international financial markets. This is a common practice in Croatia.

${ }^{20}$ Specifically, in Bulgaria and Croatia the shares of foreign currency debt in total debt amount to $81 \%$ and $72 \%$ respectively, while the shares of debt held by non-residents are much lower, at $44 \%$ and $33 \%$. By contrast, in Poland and the Czech Republic, which are much less euroized, the shares of foreign currency debt are actually lower than the shares of debt held by non-residents ( $28 \%$ and $11 \%$, compared to $44 \%$ and $41 \%$ ), suggesting that foreign investors hold non-negligible stocks of domestic currency debt issued by these two countries.
} 


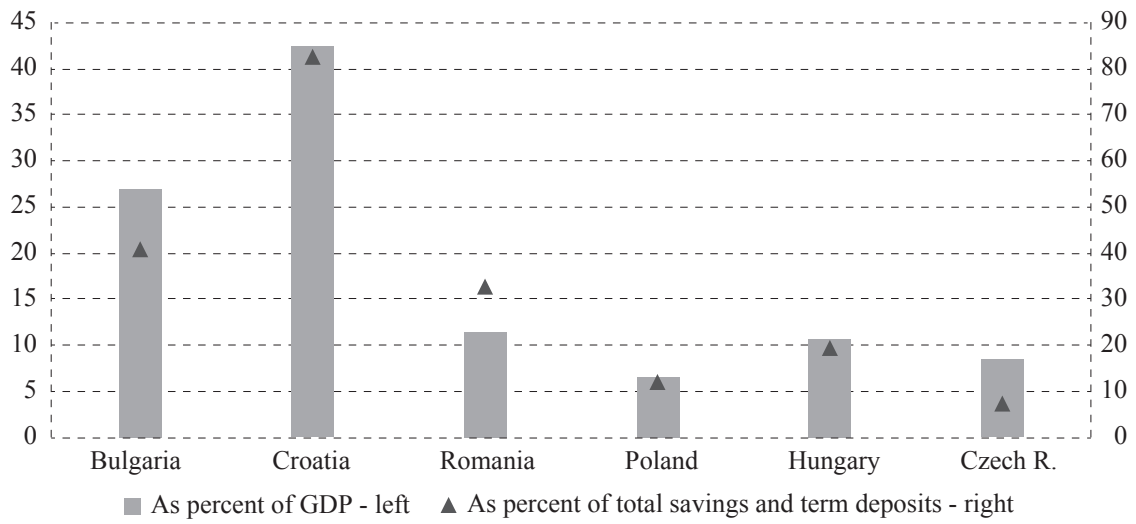

Sources: Eurostat (2020b); national central banks; author's calculations.

As argued in the previous chapters, large stocks of foreign currency deposits pose a threat to financial stability, because they impair the ability of the central bank to act as lender of last resort. Therefore, in highly dollarized (euroized) banking systems, it is critical for central banks to maintain abundant foreign exchange reserves. The importance of reserves is even greater if banking system dollarization exists alongside large government debt in foreign currency. Some CEE countries suffer from both of these problems. Figure 8 compares, for each country of the group, the level of liabilities in foreign currency - as represented by foreign currency deposits and government debt in foreign currency - with the level of central bank foreign exchange reserves. The figure indicates that individual CEE countries differ widely with respect to the degree of currency risk exposure. Croatia and Bulgaria have the highest relative amounts of foreign currency liabilities, far exceeding, in the case of Croatia, the available stock of foreign exchange reserves. The Czech Republic, on the other hand, has accumulated in recent years an extremely high stock of reserves against a very low level of foreign currency liabilities. It is therefore safe to say that the Czech Republic is significantly less sensitive to exchange rate fluctuations than Croatia and Bulgaria.

Admittedly, the illustration given in figure 8 does not provide a full picture of the countries' exposure to currency risk. First, it does not take note of the private sector's external debt. Second, the data on government foreign currency debt presented in this figure includes liabilities that are indexed to foreign currency, but repaid in local currency, which means that the government is not required to use foreign currency to service this debt. In other words, settling this part of the debt does not put pressure on foreign exchange reserves. Third, foreign currency deposits are not the only potential drain on reserves stemming from private sector behaviour. The reason is that local currency deposits and local currency in circulation can also contribute to the depletion of foreign exchange reserves if citizens, worried that the local currency could collapse, start buying foreign currency on a large scale. Nonetheless, 
while not a perfect indicator, the level of foreign currency deposits still contains important information as it reveals the extent to which citizens trust their own currency (Honohan, 2007). If confidence in the local currency is low, as evidenced by a high share of foreign currency deposits in total deposits, it is more likely that citizens will rush to convert their remaining local currency holdings into foreign currency if the local currency actually begins to depreciate. It is therefore reasonable to assume that in the event of currency depreciation heavily euroized countries like Croatia and Bulgaria would experience a faster depletion of reserves than Poland or the Czech Republic, where confidence in local currencies seems to be higher.

\section{Figure 8}

Foreign currency liabilities and gross international reserves, 2018, in percent of GDP

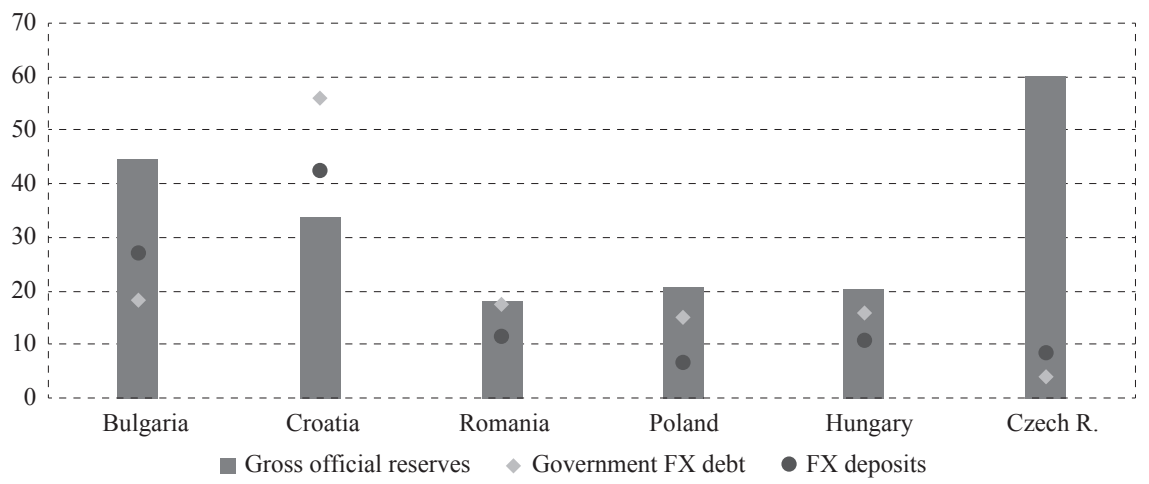

Source: Eurostat (2020c); national central banks; author's calculations.

\subsection{THE STATE OF MACROECONOMIC FUNDAMENTALS IN NON-EURO AREA EU MEMBER STATES}

In the years following the global financial crisis, countries from Central and Eastern Europe have enjoyed a sustained, well-balanced economic growth supported by accommodative monetary policies and the recovery of the main trading partners from the EU. Compared to the pre-crisis period, this is a large switch in the pattern of growth. Until the outbreak of the crisis in 2008, most CEE countries had experienced a strong domestic demand-driven expansion fuelled by massive debtcreating capital inflows. The period of abundant capital flows ended with the escalation of the global crisis, and CEE countries had to adapt to this by cutting down on private and public spending. In Hungary and Romania, the required macroeconomic adjustment and capital outflows were so large that their authorities resorted to financial assistance from the IMF and the EU to make the transition easier. Although painful at the beginning, this rebalancing set the stage for a healthy recovery in the following years.

The data depicted in figure 9 confirm that external fundamentals of the CEE countries have improved considerably since the global financial crisis. Previously large current account deficits have narrowed or even turned into surpluses, while the net international investment position increased markedly in most cases, mainly due to 
a decline in non-FDI liabilities and an increase in international reserves. ${ }^{21}$ On the fiscal front, after several years of large crisis-driven budget deficits, from 2015 until the outbreak of the COVID-19 pandemic most CEE countries showed solid fiscal performance facilitated by positive nominal GDP growth and, consequently, strong revenue collection. The government debt-to-GDP ratios were declining rapidly, which applies also to Croatia and Hungary, whose debt levels are highest in this group of countries (figure 10). The favourable dynamics on the fiscal front were, however, interrupted in early 2020 by the adverse economic consequences of the ongoing COVID-19 pandemic.

\section{Figure 9}

\section{External fundamentals of CEE countries, 2007 and 2018, in percent of GDP}

a) Current account balance and NIIP

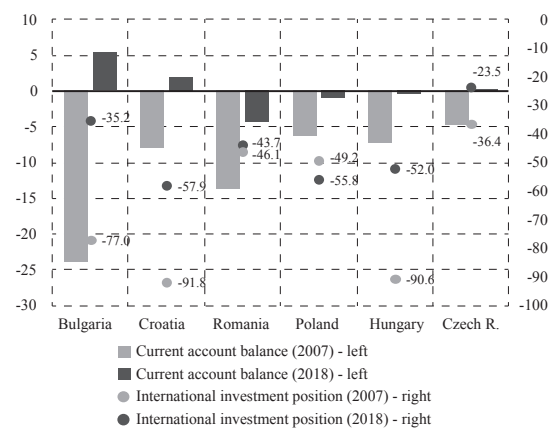

Source: IMF (2020d). b) International reserves

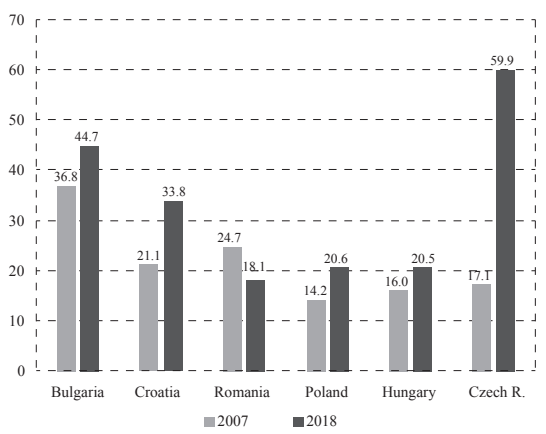

\section{Figure 10}

Fiscal indicators of CEE countries, 2007-2018, in percent of GDP

a) Fiscal balance

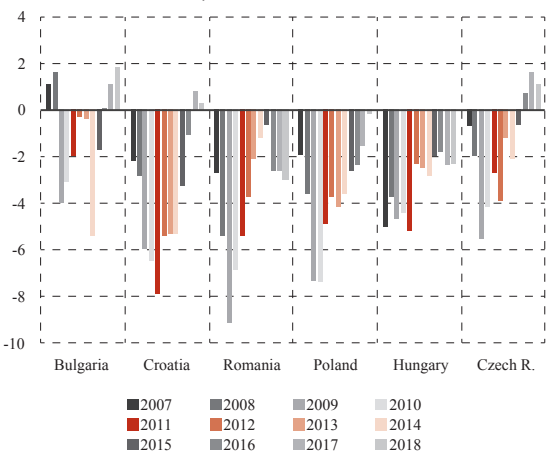

b) Government debt

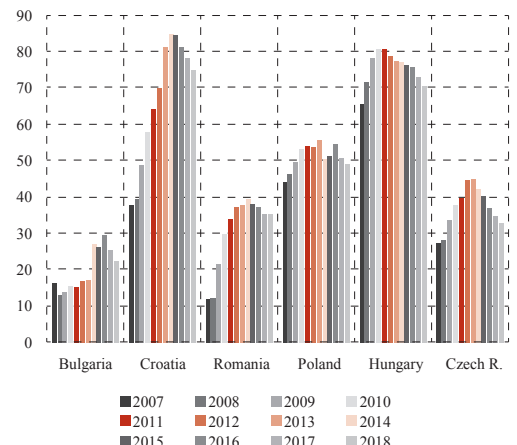

Source: Eurostat (2020a).

\footnotetext{
${ }^{21}$ The Czech Republic is a special case, as it experienced an increase in both international reserves and nonFDI liabilities from 2007 to 2018. This was partly driven by the Czech National Bank's decision of November 2013 to introduce an exchange rate floor with the aim of stimulating recovery and fending off deflationary pressures. This decision triggered large speculative non-FDI flows to the Czech Republic, as investors expected the koruna to strengthen against the euro once the floor has been removed. In 2017 alone, the central bank bought as much as EUR 42.5 billion (22\% of GDP) in the foreign exchange market to defend the floor (Czech National Bank, 2018).
} 
There have been other factors, apart from stronger external and fiscal positions, that have also contributed to reducing the exposure of non-euro area EU member states to currency risk. One of these factors is the moderate decline in loan and deposit euroization since 2008 (Dumičić, Ljubaj and Martinis, 2018). In particular, the prolonged period of very loose monetary policies worldwide has enabled central banks in CEE to create substantial local currency liquidity without jeopardizing exchange rate stability. Banks in turn have made use of the excess liquidity by issuing local currency loans, whose share in total bank loans consequently increased. In some countries, deposit euroization decreased too, as many depositors decided to transfer funds from foreign currency time deposits - which in recent years have been carrying interest rates close to zero - to demand deposits in local currency (Ljubaj and Petrović, 2016). Moreover, the high surplus liquidity in CEE banking systems has allowed their governments to replace to some extent external borrowing with borrowing from domestic banks in local currencies. This has led to a modest decline in the foreign currency component of the debt. In Croatia, for example, the share of non-residents in the ownership composition of government debt fell by close to 9 percentage points (from $41.6 \%$ to $32.7 \%$ ) in the period 2015-2018. This was associated with an 8 pp drop (from $79.5 \%$ to $71.6 \%$ ) in the share of foreign currency debt in total debt over the same period.

Finally, when discussing the sensitivity of CEE countries to currency risk, one should also take into account the high degree of integration of their economies with the euro area. The level of integration matters because the euro is the currency in which the largest part of CEE countries' foreign currency debt is denominated. The unpleasant historical experience of some emerging market countries, as documented in chapter 2, is a reminder that it can be very risky for a country to borrow heavily in a major foreign currency, if there are only loose connections with the country issuing the major currency. In particular, in the 1970s, Latin American countries accumulated large stocks of US dollar liabilities, while their economic ties with the US were relatively weak. In such an environment, there was a risk that monetary policy of the Federal Reserve would not always suit their needs. ${ }^{22}$ This risk materialized in the early 1980s when the Fed decided to raise policy rates considerably to combat high inflation. The sharp increase in interest rates made it difficult for heavily indebted Latin American countries to service their dollar debts: not only did interest rates on their debts increase, but also their local currencies depreciated against the dollar, raising the real value of the dollar debt.

Such a scenario is less likely in Europe, given that the degree of integration is much higher than in Latin America and elsewhere (figure 11). Specifically, as non-euro area EU member states are in trade and financial terms tightly integrated with the euro area, economic shocks that hit these countries are highly synchronized with

\footnotetext{
${ }^{22}$ If economic ties between two countries are weak, the correlation of their business cycles is likely to be low, so monetary policy tailored to the needs of one of them will not necessarily be appropriate for the other. For example, if the anchor country is in a more mature phase of the economic expansion than the follower country, it may choose to raise interest rates to prevent its economy from overheating, and this in turn could depress growth in the follower country, which would prefer monetary policy to remain unchanged.
} 
those affecting euro area members (Deskar-Škrbić, Kotarac and Kunovac, 2019). For this reason, monetary policy decisions of the ECB, tailored to the needs of euro area countries, are unlikely to have a dramatic negative impact on the currencies and economies of non-euro area countries. This leads to the tentative conclusion that borrowing in euros for well-integrated non-euro EU member states is probably less risky than borrowing in US dollars for Latin American and Asian countries.

\section{Figure 11}

Geographical composition of merchandise trade of selected countries, 2018

a) Non-euro EU member states (in \%)

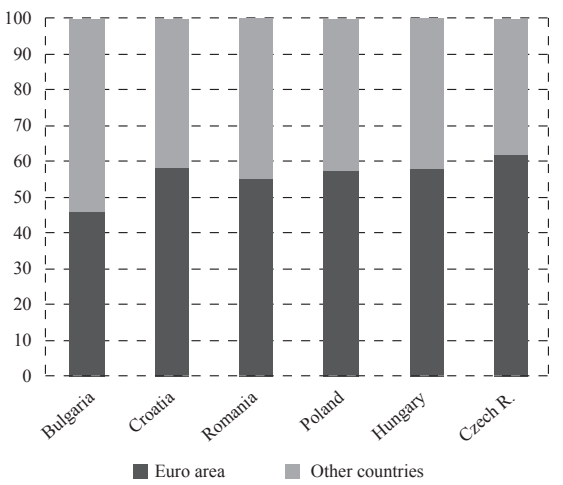

b) Latin American and Asian countries (in \%)

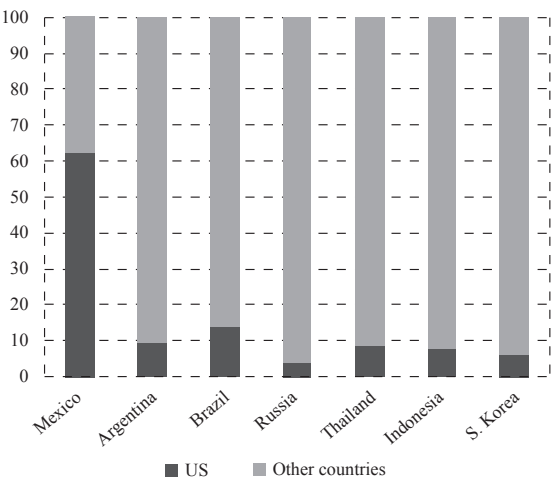

Source: IMF (2020c).

In view of the findings of the simple analysis given in this chapter, it appears that government borrowing in foreign currency is not an important source of risk in the EU. The total size of government debt denominated in or indexed to a foreign currency is low - just over $2 \%$ of EU GDP. In only two countries - Bulgaria and Croatia - does the foreign currency component (most of which are euro-denominated liabilities) account for a large majority of total government debt. Even these countries seem unlikely to experience a currency or sovereign debt crisis, as their fiscal and external fundamentals are sound and international reserves sizeable. Their resilience became apparent during the crisis triggered by the outbreak of the COVID-19 pandemic, when both countries were able to adopt sizeable fiscal stimulus programs to support the economy without compromising the stability of their currencies and public finances (European Commission, 2020).

Not surprisingly, the countries whose exposure to currency risk is the highest are the first of the remaining non-euro area EU member states to take concrete steps towards the introduction of the euro. Specifically, following the implementation of a number of pre-entry policy commitments, in July 2020, Bulgaria and Croatia joined the Exchange Rate Mechanism (ERM II), which is the final stage of the euro adoption process. The Romanian authorities have announced that they will initiate the same process in the coming years. Meanwhile, other EU member states outside the euro area have not yet expressed interest in adopting the euro. This can be partly explained by their relatively low exposure to currency risk. In particular, 
given that currency mismatches are contained, the benefits of adopting the euro and eliminating currency risk do not seem very large from their perspective, making the euro adoption less attractive as a policy anchor.

\section{CONCLUSION}

There are at least three reasons why borrowing in foreign currency is more risky for a country than borrowing in its domestic currency. First, when a large percentage of government debt is denominated in foreign currency, public finances are highly sensitive to exchange rate fluctuations. In the case of depreciation, the debt-to-GDP ratio would increase immediately, while the fiscal balance would be negatively affected by higher interest expenses. Second, heavy indebtedness in foreign currency leaves the country vulnerable to sudden shifts in investor sentiment, as investors are aware that the country might experience a shortage of foreign currency if many investors decided not to roll over their investments. Third, if investors really start withdrawing funds from the sovereign debt market, thus exerting pressure on the currency, the central bank's capacity to cope with the debt and currency crisis will be constrained, as this capacity depends entirely on the size of its foreign exchange reserves.

The ability of the central bank to intervene is much greater in countries whose government debt is mostly denominated in local currency. Even if investors choose not to finance such a country any longer, its central bank can print more money - by lending to commercial banks or by purchasing bonds in the secondary market - in order to help the government refinance its liabilities. This is exactly what the European Central Bank did during the 2010-2012 European sovereign debt crisis and what it has been doing following the outbreak of the COVID-19 pandemic in early 2020. There is little doubt that these two crises would have been much worse had the ECB not intervened in such a way. In this regard, dependence on foreign currency borrowing could definitely be considered a "curse", as it makes the country both more likely to experience a negative shift in investor sentiment and less capable of managing the sovereign debt crisis if a negative shift does occur.

While the government's indebtedness in foreign currency is certainly a source of vulnerability, it does not necessarily lead to a debt crisis. The historical episodes documented in this paper clearly show that debt and currency crises are likely when the government is borrowing too much on short maturities, when reserves are insufficient, the real exchange rate is overvalued and credit growth is excessive. In contrast, the probability of a crisis is likely to be low if the authorities implement a prudent policy mix; if the government maintains a balanced budget, the debt-to-GDP ratio is relatively low and the average maturity of debt is long, it is unlikely that the country will have difficulty refinancing the debt, regardless of its unfavourable currency composition. The maintenance of ample foreign currency reserves is also important, for it signals to investors that the government will be able to meet its obligations even if it temporary loses access to international financial markets. It is also vital to carry out vigorous supervision and regulation 
of the financial sector, as failures of large banks can impose a heavy burden on public finances and thus undermine debt sustainability.

Public finances of non-euro area EU member states do not appear to be heavily exposed to currency risk. In the event of a sharp depreciation of their currencies, the resulting increase in the debt-to-GDP ratio would be mild in most cases. Even countries with a relatively high share of foreign currency debt in total government debt, such as Bulgaria and Croatia, are unlikely to have trouble with debt refinancing in the near future owing to their generally robust fiscal and overall macroeconomic performance. Their resilience was demonstrated after the outbreak of the COVID-19 pandemic when both countries were able to implement significant fiscal stimulus programs to support the economy while keeping their currencies and public finances stable. However, from a long-term perspective, these two countries have every reason to adopt the euro. Apart from the fact that their government debt consists mainly of euro-denominated liabilities, the two countries stand out with persistently high levels of loan and deposit euroization, which is an additional major source of vulnerability. The introduction of the euro would bring substantial benefits to Bulgaria and Croatia in terms of lower risk exposure and higher resilience to financial crises. It is therefore not surprising that Bulgaria and Croatia are the first among the remaining non-euro area EU member states to express interest in joining the ERM II and introducing the euro. For all other member states, except Romania, the net economic benefit of adopting the euro appears to be smaller, which partly explains why their authorities do not have the ambition to launch the euro adoption process any time soon.

\section{Disclosure statement}

No potential conflict of interest was reported by the author. 


\section{REFERENCES}

1. Abiad, A., 2003. Early-Warning Systems: A Survey and a Regime Switching Approach. IMF Working Papers, No. 03/32. Washington: International Monetary Fund. https://doi.org/10.5089/9781451845136.001

2. Babecký, J. [et al.], 2012. Banking, Debt, and Currency Crises. Early Warning Indicators for Developed Countries. Working Paper Series, No. 1485. Frankfurt am Main: European Central Bank.

3. Banco de Mexico, 2017. Quarterly Report October-December 2016. Mexico City: Banco de Mexico.

4. Brkić, M., 2019. Banking Distress in Europe in the Context of the Global Financial Crisis - the Role of Capital Flows. Surveys, S-36. Zagreb: Croatian National Bank.

5. Chang, R. and Velasco, A., 1998. Financial Crises in Emerging Markets: A Canonical Model. NBER Working Papers, No. 6606. Cambridge, MA: National Bureau of Economic Research.

6. Chang, R. and Velasco, A., 1999. Liquidity Crises in Emerging Markets: Theory and Policy. NBER Macroeconomics Annual, 14(1999), pp. 11-58. https:// doi.org/10.1086/654376

7. Chang, R. and Velasco, A., 2002. Dollarization: Analytical Issues. NBER Working Papers, No. 8838. Cambridge, MA: National Bureau of Economic Research.

8. Claessens, S., Herring, R. J. and Schoenmaker, D., 2010. A Safer World Financial System: Improving the Resolution of Systemic Institutions. Geneva and London: International Center for Monetary and Banking Studies and Centre for Economic Policy Research.

9. Claessens, S., Schmukler, S. and Klingebiel, D., 2007. Government Bonds in Domestic and Foreign Currency: The Role of Institutional and Macroeconomic Factors. Review of International Economics, 15(2), pp. 370-413. https://doi.org/10.1111/j.1467-9396.2007.00682.x

10. CNB, 2012. Annual Report 2011. Zagreb: Croatian National Bank.

11. CNB, 2020. Bulletin 261. Zagreb: Croatian National Bank.

12. Cole, H. L. and Kehoe, T. J., 2000. Self-Fulfilling Debt Crises. The Review of Economic Studies, 67(1), pp. 91-116. https://doi.org/10.1111/1467-937x. 00123

13. Constancio, V., 2012. Contagion and the European Debt Crisis. Financial Stability Review, No. 16. Paris: Banque de France.

14. Czech National Bank, 2018. Annual Report 2017. Prague: Czech National Bank.

15. Danmarks Nationalbank, 2019. Danish Government Borrowing and Debt 2018, No. 1. Copenhagen: Danmarks Nationalbank.

16. Deskar-Škrbić, M., Kotarac, K. and Kunovac, D., 2019. The Third Round of the Euro Area Enlargement: Are the Candidates Ready. Working Papers, W-57. Zagreb: Croatian National Bank. 
17. Diamond, D. W. and Dybvig, P. H., 1983. Bank Runs, Deposit Insurance, and Liquidity. The Journal of Political Economy, 91(3), pp. 401-419. https://doi. org/10.1086/261155

18. Dumičić, M., 2015. A Brief Introduction to the World of Macroprudential Policy. Surveys, S-18. Zagreb: Croatian National Bank.

19. Dumičić, M., Ljubaj, I. and Martinis, A., 2018. Persistence of Euroisation in Croatia. Surveys, S-31. Zagreb: Croatian National Bank.

20. Eichengreen, B. and Hausmann, R., 1999. Exchange Rates and Financial Fragility. NBER Working Papers, No. 7418. Cambridge, MA: National Bureau of Economic Research.

21. Eichengreen, B., Hausmann, R. and Panizza, U., 2003. Currency Mismatches, Debt Intolerance and Original Sin: Why They Are Not the Same and Why it Matters? NBER Working Papers, No. 10036. Cambridge, MA: National Bureau of Economic Research. https://doi.org/10.3386/w10036

22. Eichengreen, B., Rose, A. K. and Wyplosz, C., 1995. Exchange Market Mayhem: The Antecedents and Aftermath of Speculative Attacks. Economic Policy, 10(21), pp. 249-312. https://doi.org/10.2307/1344591

23. European Commission, 2020. European Economic Forecast - Spring 2020. Brussels: European Commission.

24. Eurostat, 2020a. Government finance statistics. Bruxelles: Eurostat.

25. Eurostat, 2020b. National accounts statistics. Bruxelles: Eurostat.

26. Federal Deposit Insurance Corporation, 1997. An Examination of the Banking Crises of the 1980s and Early 1990s. Volume 1. Washington, DC: Federal Deposit Insurance Corporation.

27. Flood, R. P. and Marion, N. P., 1996. Speculative Attacks: Fundamentals and Self-Fulfilling Prophecies. NBER Working Papers, No. 5789. Cambridge, MA: National Bureau of Economic Research. https://doi.org/10.3386/w5789

28. Frankel, J. A. and Rose, A. K., 1996. Currency Crashes in Emerging Markets: An Empirical Treatment. International Finance Discussion Papers, No. 534. Washington, DC: Board of Governors of the Federal Reserve System.

29. Gros, D., Alcidi, C. and Giovanni, A., 2012. Central Banks in Times of Crisis. The FED versus the ECB. Paper presented at the European Parliament's Committee on Economic and Monetary Affairs Monetary Dialogue with the ECB, July 9.

30. Hausmann, R., Panizza, U. and Stein, E., 2001. Why Do Countries Float the Way They Float? Journal of Development Economics, 66(2), pp. 387-414. https://doi.org/10.1016/s0304-3878(01)00168-7

31. Higgins, M. and Klitgaard, T., 2014. Saving Imbalances and the Euro Area Sovereign Debt Crisis. Current Issues in Economics and Finance, 17(5), pp. 1-11. https://doi.org/10.2139/ssrn.1925018

32. Honohan, P., 2007. Dollarization and Exchange Rate Fluctuations. World Bank Policy Research Working Papers, No. 4172. Washington, DC: World Bank. https://doi.org/10.1596/1813-9450-4172 
33. IMF, 2009. Republic of Latvia: Request for Stand-By Arrangement - Staff Report. IMF Country Reports, No. 09/3. Washington, DC: International Monetary Fund.

34. IMF, 2020a. World Economic Outlook, April 2020: The Great Lockdown. Washington, DC: International Monetary Fund.

35. IMF, 2020b. Monetary and financial statistics. Washington: International Monetary Fund.

36. IMF, 2020c. Direction of Trade Statistics. Washington: International Monetary Fund.

37. IMF, 2020d. Balance of payments statistics and international investment positions. Washington: International Monetary Fund.

38. Kaminsky, G. L. and Reinhart, C. M., 1999. The Twin Crises: The Causes of Banking and Balance-of-Payments Problems. American Economic Review, 89(3), pp. 473-500. https://doi.org/10.1257/aer.89.3.473

39. Kaminsky, G. L., Reinhart, C. M. and Végh, C. A., 2005. When It Rains, It Pours: Procyclical Capital Flows and Macroeconomic Policies. In: M. Gertler and K. Rogoff, eds. NBER Macroeconomics Annual, 19(2004), pp. 11-53. Cambridge, MA: National Bureau of Economic Research.

40. Kaminsky, G., Lizondo, S. and Reinhart, C., 1998. Leading Indicators of Currency Crises. Staff Papers, 45(1), pp. 1-48. https://doi.org/10.2307/3867328

41. Kruger, M., Osakwe, P. N. and Page, J., 1998. Fundamentals, Contagion and Currency Crises: An Empirical Analysis. Working Papers, No. 98-10. Ottawa: Bank of Canada.

42. Ljubaj, I. and Petrović, S., 2016. A Note on Kuna Lending. Surveys, S-21. Zagreb: Croatian National Bank.

43. Ljubaj, I., 2019. Međunarodne pričuve, tečajne razlike i financijski rezultat poslovanja HNB-a. Pregledi, P-45. Zagreb: Hrvatska narodna banka.

44. Micossi, S., 2015. The Monetary Policy of the European Central Bank (20022015). CEPS Special Reports, No. 109. Brussels: Centre for European Policy Studies.

45. MoF, 2017. Public Debt Management Strategy 2017-2019. Zagreb: Ministry of Finance of the Republic of Croatia.

46. Obstfeld, M., 1986. Rational and Self-Fulfilling Balance-of-Payments Crises. NBER Working Papers, No. 1486. Cambridge, MA: National Bureau of Economic Research. https://doi.org/10.3386/w1486

47. Obstfeld, M., 1994. The Logic of Currency Crises. NBER Working Papers, No. 4640. Cambridge, MA: National Bureau of Economic Research. https:// doi.org/10.3386/w4640

48. Purfield, C. and Rosenberg, C., 2010. Adjustment Under a Currency Peg: Estonia, Latvia and Lithuania During the Global Financial Crisis 2008-09. IMF Working Papers, No. 10/213. Washington, DC: International Monetary Fund. https://doi.org/10.5089/9781455205448.001

49. Ritschl, A., 2013. Reparations, Deficits, and Debt Default: the Great Depression in Germany. In: N. Crafts and P. Fearon, eds. The Great Depression of the 
1930s. Lesson for Today. London: Oxford University Press, pp. 110-139. https://doi.org/10.1093/acprof:oso/9780199663187.003.0004

50. Sachs, J., Tornell, A. and Velasco, A., 1996. The Collapse of the Mexican Peso: What Have We Learned? Economic Policy, 11(22), pp. 13-63. https:// doi.org/10.2307/1344521

51. Sahay, R. [et al.], 2014. Emerging Market Volatility: Lessons from the Taper Tantrum. IMF Staff Discussion Notes, No. 14/09. Washington, DC: International Monetary Fund. https://doi.org/10.5089/9781498318204.006

52. Swedish National Debt Office, 2019. Guidelines for Central Government Debt Management 2020. Stockholm: Swedish National Debt Office.

53. Vlaar, P. J. G., 2000. Early Warning Systems for Currency Crises. BIS conference papers, 8, pp. 253-274. 